\title{
Virus-like particles in an apochlorotic flagellate in Hiroshima Bay, Japan
}

\author{
Keizo Nagasaki ${ }^{1}$, Masashi Ando ${ }^{2}$, Ichiro Imai ${ }^{1}$, Shigeru Itakura ${ }^{1}$, Yuzaburo Ishida ${ }^{3}$ \\ ${ }^{1}$ Red Tide Biology Section, Red Tide Research Division, Nansei National Fisheries Research Institute, Ohno-cho, Saeki-gun, Hiroshima 739-04, Japan \\ ${ }^{2}$ Department of Fisheries, Faculty of Agriculture, Kinki University, Nara 631, Japan \\ ${ }^{3}$ Department of Fisheries, Faculty of Agriculture, Kyoto University, Kyoto 606, Japan
}

\begin{abstract}
Virus-like particles (VLPs) were detected in an apochlorotic flagellate (species unknown) in a water specimen obtained from a bloom of Prorocentrum triestinum (Dinophyceae) in northern Hiroshima Bay, Japan. The cells containing VLPS were discovered in a natural water specimen and were estimated to be about $20 \%$ of the apochlorotic cell population. The VLPs were pentagonal or hexagonal in cross section, indicating icosahedral symmetry, and were associated with the viroplasm (virogenic stroma). It is suggested that viral infection may be one of the important factors regulating the dynamics of heterotrophic flagellates in aquatic environments.
\end{abstract}

Recently, the concentration of virus particles in various aquatic environments was measured as $10^{6}$ to $10^{9} \mathrm{ml}^{-1}$, much higher than had been estimated by plaque assay method (Bergh et al. 1989, Bratbak et al. 1990, Suttle et al. 1990, Hara et al, 1991). Therefore, it is of great interest to clarify their role in aquatic environments and the interaction between them and aquatic microorganisms.

Studies on viruses infectious to bacteria (Hidaka 1972, Børsheim et al. 1990, Heldal \& Bratbak 1991, Bratbak et al. 1992) and algae (Dodds 1979, Sieburth et al. 1988, Cottrell \& Suttle 1991, Van Etten et al. 1991, Yamada et al. 1991) in aquatic environments have been carried out recently. On the basis of these reports, viruses have been recognized as active members of the microbial food web in aquatic ecosystems.

However, as far as we know, information on viruses infectious to aquatic heterotrophic flagellates, the ecological importance of which as grazers of bacteria has been highlighted recently (Sherr et al. 1986), is scant except for virus-like particles (VLPs) in Aulacomonas Skuja cultured with Scenedesmus obliquus as prey (Swale \& Belcher 1973).
In the present paper, we describe VLPs observed in an apochlorotic flagellate (species unknown) in natural water of Hiroshima Bay, Japan.

Materials and methods. During a bloom of Prorocentrum triestinum in Hiroshima Bay, Seto Inland Sea, Japan, on 19 June 1992, surface water (ca 2 1) was collected. Cells in the water specimen were prepared for electron microscopy to a great extent according to the method described by Hara \& Chihara (1982). Thin sections were viewed with JEOL JEM-1010 and Hitachi $\mathrm{H}-800$ transmission electron microscopes.

Results and discussion. In the sections, a kind of flagellate, the form of which was roundish but changeable, ca 5 to $8 \mu \mathrm{m}$ in diameter, was frequently observed (Fig. 1) as well as Prorocentrum triestinum. The flagellate was phagotrophic and each cell had several food vacuoles, some of which were packed with smaller prey being digested. As all the observed cells lacked chloroplasts, we regarded them as apochlorotic flagellates. Intracellular plate structure typically showed a cornice-like cross section, the pattern of which appeared subtly different in the sections (arrows in Fig. 1). An apochlorotic flagellate which was reported as a predator of the brown tide organism Aureococcus anophagefferens by Sieburth et al. (1988) also has a very similar structure. As little morphological information was obtained by light microscopy, we could not identify the flagellate.

Some of the cells were found to harbor VLPs (Figs. 2 \& 3). As 8 out of 42 cells in 2 different blocks contained VLPS, the frequency of the cells with VLPS was tentatively estimated to be about $20 \%$, suggesting that nearly the whole population was at a lytic stage (Proctor \& Fuhrman 1990). Except for those released to 

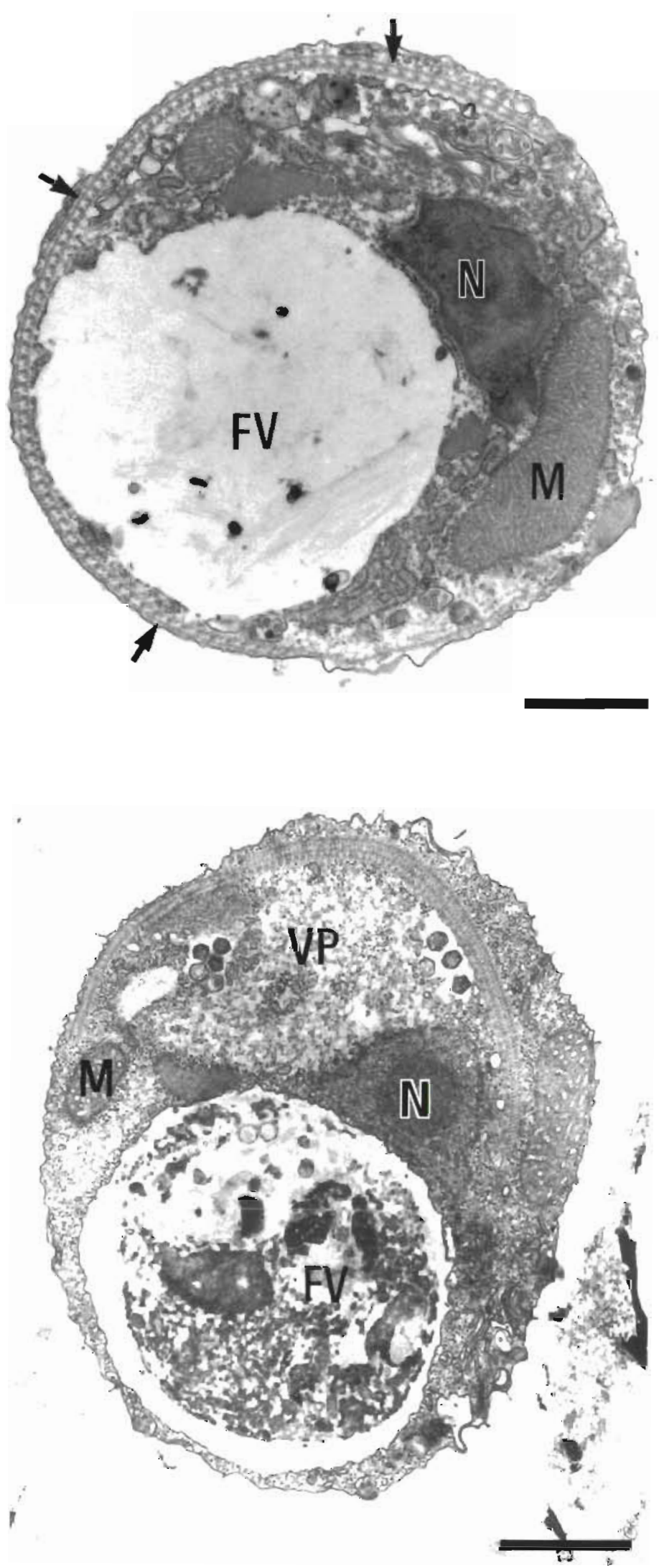

- Fig. 1. Electron micrograph of an apochlorotic flagellate frequently observed in the red-tide specimen. Arrows indicate the plate structure showing a cornice-like cross section characteristic of this flanglate, the pattern of which appears subtly different in the sections. $\mathrm{N}$ : nucleus; $\mathrm{M}$ : mitochondrion; FV: food vacuole. Scale bar $=1 \mu \mathrm{m}$

the cytoplasm or exterior of the cell, the VLPs were associated with the viroplasm. The VLPs were usually pentagonal or hexagonal in cross section suggesting that they were icosahedral in 3-dimensional morphology. No tails could be observed. The coat measured ca 13 to $15 \mathrm{~nm}$ thick, around an osmiophilic-lucent fibrillar core (Fig. 4).

Considering the previous reports on viroplasms, there seem to be at least 2 types of mechanism for their generation. In one case, the intact nucleus exists apart from the viroplasm (Preisig \& Hibberd 1984); in the other, the nucleus itself is degenerated to form viroplasm (Swale \& Belcher 1973). It seems that the ultrastructural observation. in the present study corresponds to the former, i.e. the nucleus remained apart from the viroplasm. Although these cells were probably moribund, mitochondria and food vacuoles also appeared to be intact. Further, in collapsing cells, the viroplasm separated from the cytoplasm (Figs. $2 \& 3$ ), and apparent budding of VLPs from the periphery of the viroplasm was clearly observed (small arrows in Fig. 4). The VLPs appeared to emanate from the viroplasm to the cytoplasm. As ribosomal aggregates were also observed both inside and around the circumference of viroplasms (Fig 3), it was suggested that proteins had been intensively synthesized for the construction of VLPS.

The observations suggest that viral infection may be one of the important factors regulating the dynamics of heterotrophic flagellates in aquatic environments, as is

4 Fig. 2. Electron micrograph of a cell contaning VLPs in a relatively early stage of viral replication. Viroplasm does not separate from the cytoplasm, and several VLPS are observed sporadically. Origin of 2 empty VLPs in the food vacuole is unknown. Scale bar $=1 \mu \mathrm{m}$. Abbreviations as in Fig. 1; VP: viroplasm 
Fig. 3. Electron micrograph of a collapsing cell which releases numerous VLPS. Nucleus, mitochondria, food vacuoles and plate structure (small arrows) appear intact. Note that the viroplasm separates from the cytoplasm and many 't.Ps are released. Ribosomal aggregations are seen both inside the viroplasm (large arrows) and around the circumference (arrow heads). Scale bar $=1 \mu \mathrm{m}$. Abbreviations as in Fig. 2

Fig. 4. Higher magnification of viroplasm periphery. VLPS 'budding' from the viroplasm are clearly observed (small arrows). Note the incompletely formed particles enclosing only weakly staining core matenal (large arrows). Scale bar $=200 \mathrm{~nm}$. Abbreviation as in Fig. 2
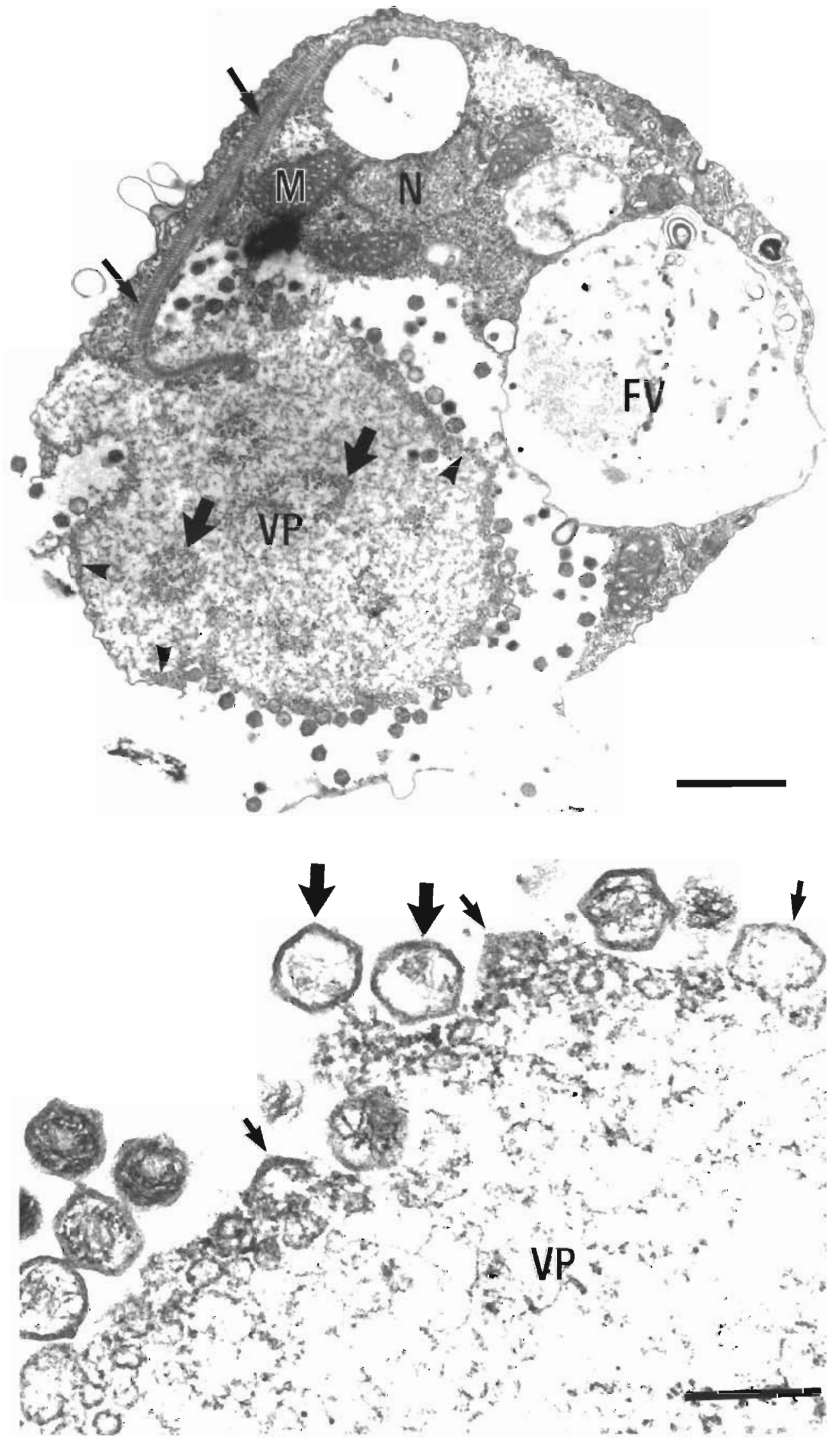
the case with bacteria and autotrophic microorganisms (Sieburth et al. 1988, Bratbak et al. 1990, Suttle et al. 1990, Cottrell \& Suttle 1991, Van Etten et al. 1991). Since it is suggested that they influence algicidal bacteria by grazing (Imai et al, in press), the ecological importance of viruses infectious to heterotrophic flagellates should be noted with regard to algal blooms.

Acknowledgements. We thank Drs $\mathrm{Y}$ Makinodan and $\mathrm{T}$. Nakagawa of Kinki University, Drs T Honjo, M. Yamaguchi, $\mathrm{N}$. Suzuki and Mr Goto of the Nansei National Fisheries Research Institute, and JEOL Ltd for their help during the work. This work was supported in part by a grant from the Fisheries Agency of Japan.

\section{LITERATURE CITED}

Bergh, Ø., Børsheim, K. Y., Bratbak, G., Heldal, M. (1989). High abundance of viruses found in aquatic environments. Nature 340: 467-468

Børsheim, K. Y., Bratbak, G., Heldal, M. (1990). Enumeration and biomass estimation of planktonic bacteria and viruses by transmission electron microscopy. Appl environ. Microbiol. 56: 352-356

Bratbak, G., Heldal, M., Norland, S., Thingstad, T. F. (1990). Viruses as partners in spring bloom microbial trophodynamics. Appl. environ. Microbiol. 56: 1400-1405

Bratbak, G., Heldal, M., Thingstad, T. F, Riemann, B., Haslund, O. H. (1992). Incorporation of viruses into the budget of microbial C-transfer. A first approach. Mar. Ecol. Prog. Ser. 83: 273-280

Cottrell, M. T., Suttle, C. A. (1991). Wide-spread occurrence and clonal variation on viruses which cause lysis of a cosmopolitan, eucaryotic marine phytoplankter, Micromonas pusilla. Mar. Ecol. Prog. Ser. 78: 1-9

Dodds, J. A. (1979). Viruses of marine algae. Experientia 35: $440-442$

Hara, S., Terauchi, K., Koike, I. (1991). Abunclance of viruses

This note was presented by K. Furuya, Tsu, Japan in marine waters: assessment by epifluorescence and transmission electron microscopy. Appl. environ. Microbiol. 57: 2731-2734

Hara, Y., Chihara, M. (1982). Ultrastructure and taxonomy of Chattonella (class Raphidophyceae) in Japan. Jap. J. Phycol. 30: 47-56

Heldal, M. Bratbak, G. (1991). Production and decay of viruses in aquatic environments. Mar. Ecol. Prog. Ser. 72 $205-212$

Hidaka, T. (1972). On the stability of marine bacteriophages. Nippon Suisan Gakk. 38: 517-523

Imai, I., Ishida, Y., Hata, Y. (in press). Killing of marine phytoplankton by a gliding bacterium Cytophaga sp., isolated from the coastal sea of Japan. Mar. Biol.

Preisig, H. R., Hibberd, D. J. (1984). Virus-like particles and endophytic bacteria in Paraphysomonas and Chromophysomonas (Cryptophyceae). Nord. J. Bot. 4: 279-285

Proctor, L. M., Fuhrman, J. A. (1990). Viral mortality of bacteria and cyanobacteria. Nature 343: 60-62

Proctor, L. M., Fuhrman, J. A. (1991). Roles of viral infection in organic particle flux. Mar. Ecol. Prog. Ser. 69: 133-142

Sherr, E. B., Sherr, B. F., Paffenhöfer, G.-A. (1986). Phagotrophic protozoa as food for metazoans: a 'missing' trophic link in marine pelagic food webs? Mar. microb. Fd Webs 1: $61-80$

Sieburth, J. M., Johnson, P. W., Hargraves, P. E. (1988). Ultrastructure and ecology of Aureococcus anophagefferens gen. et nov. (Chrysophyceae): the dominant picoplankter during a bloom in Narragansett Bay, Rhode Island, summer 1985. J. Phycol. 24: 416-425

Suttle, A. C., Chen, A. M., Cottrell, M. T. (1990). Infection of phytoplankton by viruses and reduction of primary productivity. Nature 347: 467-469

Swale, E. M. F., Belcher, J. H. (1973). A light and electron microscope study of the colorless flagellate Aulacomonas Skuja. Arch. Mikrobiol. 92: 91-103

Van Etten, J. L., Lane, L. C., Meints, R. H. (1991). Viruses and virus-like particles of eucaryotic algae. Microbiol. Rev. 55 : $586-620$

Yamada, T., Higashiyama, T., Fukuda, T. (1991). Screening of natural waters for viruses which infect Chlorella cells. Appl. environ. Microbiol. 57: 3433-3437

Manuscript first received: March 1, 1993

Revised version accepted: April 20, 1993 